\title{
Appointment of independent trustees - A consequence of the economic downturn
}

Received: 10th April, 2003

\section{Philip Goodchild}

is Senior Assistant Solicitor within the Employment Pensions and Benefits Group at Stephenson Harwood. Philip was admitted as a solicitor in November 1995 and specialises in pensions law advising both trustees and employers in all aspects of this varied practice area including drafting pensions documentation, providing day-to-day advice on the running of occupational pension scheme arrangements and advising on the pension aspects of corporate transactions. Philip is a member of the Association of Pensions Lawyers.

\begin{abstract}
This paper discusses the author's view that the economic downturn has increased interest in the requirements for the statutory appointment of independent trustees and the law relating to their appointment to occupational pension schemes where an insolvency practitioner is appointed to a sponsoring employer of the scheme. The paper also discusses the statutory test of 'independence' applied to assess whether a person or body is 'independent' for the purposes of being eligible for appointment as an independent trustee under the pensions Act 1995 and goes on to cover the disclosure of information requirements triggered by the appointment and the powers of an independent trustee. Finally, the paper discusses the circumstance in which the requirements for an independent trustee under the Pensions Act will end.
\end{abstract}

Keywords: independent trustee appointment; legislation requiring appointment; exemptions to appointment; multi-employer pension schemes; definition of 'independent'; disclosure requirements; independent trustee paths; independent trustee payments; cessation of appointments

\section{Introduction}

The economic downturn and the consequent increase in the number of companies finding themselves in financial difficulty has led to an increase in enquiries from pension scheme trustees, sponsoring employers and insolvency practitioners as to what statutory requirements there are to appoint an independent trustee to the pension

Philip Goodchild Stephenson Harwood, 1 St Paul's Churchyard, London EC4M 8SH, UK.

Tel: +44 (0)20 7809 2166; Fax: +44 (0)20 7867 0018; E-mail: philip.goodchild@ shlegal.com scheme in which the company either participates or is the principal employer. This paper discusses the legislation requiring the appointment of an independent trustee and the consequences of such an appointment.

\section{Appointment of independent trustees under statute}

Although independent trustee legislation was first introduced by the Social Security Act 1990, the statutory requirements for independent trustees are presently governed by Sections 22 to 26 of the Pensions Act 1995 (the Act) and the Occupational Pension Schemes (Independent Trustee) Regulations 1997 (Independent Trustee Regulations) with effect on and from 6th April, 1997.

Under the present legislation, if, in relation to an occupational pension scheme which is established under trust: 
- an insolvency practitioner is appointed in relation to an employer participating in the scheme; or

- the receiver and the manager, or the trustee, of the estate of a bankrupt who is an employer; or

- the official receiver becomes the liquidator or provisional liquidator of a company which is an employer,

then it is the duty of the insolvency practitioner or official receiver to satisfy himself that, at all times, at least one of the trustees of the scheme is an independent person. In the event that the insolvency practitioner or the official receiver are not satisfied that this is the position, then he must appoint or secure the appointment of an independent person as a trustee of the scheme within three months, beginning with the date on which he first becomes aware that s. $22^{1}$ applies or on the date when the duty arises, whichever is the later.

An insolvency practitioner will include liquidators, administrators and administrative receivers. It should also be noted that this duty is a continuing duty and that it lasts as long as the insolvency practitioner is in office. Consequently, if an insolvency practitioner is satisfied at the beginning of his appointment that at least one of the trustees is independent, he must nevertheless continually review the position throughout his appointment and, if circumstances change so that he is no longer satisfied that at least one trustee is independent, then he must appoint or secure the appointment of an independent trustee in accordance with the legislation.

\section{Exemptions}

The requirement to appoint an independent trustee is subject to certain exemptions set out in the Independent Trustee Regulations. ${ }^{2}$
Sections 22 to $26^{3}$ do not apply to any of the following schemes:

- a scheme of which each member is a trustee

- a money purchase scheme

- a scheme:

(i) where the only benefits provided are death benefits; and

(ii) under the provisions of which no member has accrued rights

- a scheme under which all the benefits to be provided are secured by one or more policies of insurance or annuity contracts and such policies or contracts are specifically allocated to the provision of benefits for individual members or any other person who has a right to benefits under the scheme

- a scheme which would be a money purchase scheme but for the fact that it provides guaranteed minimum pensions

- a scheme which provides relevant benefits but is neither an approved scheme nor a relevant statutory scheme

- an s. 615(6) Income \& Corporation Taxes Act 1988 scheme (a type of approved scheme for expatriates).

\section{Amendments to provisions in the case of a multi-employer scheme}

The legislation is amended by Regulation 3 of the Independent Trustee Regulations ${ }^{4}$ in relation to a multiemployer scheme (ie a scheme in relation to which there is more than one employer) in situations where an insolvency practitioner has been appointed or the official receiver has become liquidator or provisional liquidator in relation to an employer.

In these situations, the requirement for an independent trustee will only apply if the employer concerned is a trustee of the scheme or has had - within the previous three years before the requirements of $s$. 
$22^{5}$ started to apply to the scheme - sole power to appoint or remove any trustee or any director of a company which is a trustee of the scheme and no other employer has such power or another employer has the power but an insolvency practitioner has been appointed, or the official receiver has become liquidator or provisional liquidator in relation to the employer.

This provision operates to ensure that the requirement to appoint an independent trustee does not apply if, for example, a subsidiary company which participates in a parent company's group pension scheme becomes insolvent where the subsidiary has no power to appoint or remove trustees. It also operates to provide which insolvency practitioner is responsible for ensuring an independent trustee is present or is appointed where a number of insolvency practitioners have been appointed to a group of companies.

\section{Definition of independent}

Section 23(3) of the $\mathrm{Act}^{6}$ provides that a person is 'independent' for the purposes of that section only if:

- he has no interest in the assets of the employer or of the scheme, otherwise than as trustee of the scheme;

- he is neither connected with nor an associate of the employer or the insolvency practitioner or the official receiver and the following additional requirements set out in Regulation 2 of the Independent Trustee Regulations $1997^{7}$ are satisfied:

- (i) he has not provided services in relation to the scheme to the trustees of the scheme or the employer at any time since the date which fell three years before s. $22^{8}$ started to apply in relation to the scheme; and

(ii) he is not connected with, nor an associate of, a person who has provided such services since that date; and

(iii) he is neither connected with, nor an associate of, a person who has an interest in the assets of the employer or of the scheme, otherwise than as a trustee of the scheme.

'Connected' and 'associate' are as respectively defined in the Insolvency Act 1986, s. 249 and s. 435. It is not possible to list all the variations of what will amount to being connected or an associate within this paper. However, as an example, a company will be considered 'connected' with another company if the same person has control of both companies; one person has control of one company and persons 'connected' with him have control of another or a group of two or more persons has control of both companies. An 'associate' will include a person's husband (or wife), relatives, relatives' husbands or wives, husbands' or wives' relatives and a person's employer or the employee of a person.

\section{Disclosure requirements relating to the appointment of an independent trustee}

Following the appointment of an independent trustee under s. 22 of the Act, ${ }^{9}$ the trustees must supply the following information in writing to every member (other than deferred members whose addresses are not known to the trustees) or relevant trade union within two months of the appointment of the independent trustee:

- the name and address of any person who has been appointed as an independent trustee of the scheme under s. $23^{10}$ of the Act 
- the scale of fees that will be chargeable by any independent trustee and payable by the scheme

- details of the amounts charged to the scheme by any independent trustee in the past 12 months

- the name and address of any trustee who is an independent person for the purposes of s. 23(1)(a) of the Act. ${ }^{11}$

Further, trustees must provide details of the appointment of an independent trustee to:

- the Pensions Registry, within 12 months of the appointment. Failure to comply without reasonable cause is an offence; and

- the Inland Revenue, within 180 days of the appointment. Any breach of this requirement will result in the scheme administrator, who will commonly be the trustees, becoming liable to a tax penalty payable to the Inland Revenue.

Furthermore, the insolvency practitioner or official receiver appointed must provide the scheme trustees, as soon as practicable after the receipt of a request, with any information which the trustees may reasonably require for the purposes of the scheme. Any expenses incurred by the insolvency practitioner or the official receiver in complying with this request are recoverable by him as part of the expenses incurred by him in the discharge of his duties.

Further disclosure requirements have been introduced by the Child Support, Pensions and Social Security Act 2000 which has added new s. $26 \mathrm{~A}, \mathrm{~B}$ and C to the Act. ${ }^{12}$ As a result, there is a requirement for the trustees or persons involved in the administration of the scheme to make a report within a period of one month to the Occupational Pensions Regulatory Authority (Opra) if they believe that there appears to be no independent trustee appointed in circumstances where the independent trustee requirements apply to the scheme unless they have been told or have reasonable grounds to believe that the insolvency practitioner or official receiver appointed are satisfied that at least one of the trustees is independent.

However, no notification is required where it appears to the trustees or persons responsible for the management of the scheme that the insolvency practitioner or official receiver intends to appoint an independent trustee and that he will do so within a specified period or, alternatively, where it appears to the person responsible for the management of the scheme that Opra is already aware that the scheme has no trustees.

Another new disclosure requirement is that persons involved in the administration of the scheme should notify Opra within a period of one month where the employer of the scheme who is the sole trustee becomes insolvent in the absence of an assurance from the employer concerned, that there is no reason why that employer should not continue to act as trustee of the scheme. For multi-employer schemes, this requirement will only apply where all the employers are insolvent.

The requirement does not apply where it appears to those persons that Opra is already aware of the situation, or where the period of three months beginning with the date on which the independent trustee requirements would have applied has not yet elapsed.

\section{The powers of an independent trustee}

While the requirement to appoint an independent trustee under ss. $22-26^{13}$ applies to the scheme, the powers 
vested in the trustees or managers of the scheme only become exercisable by the independent trustee. Additionally, any power which the scheme confers on the employer (otherwise than as trustee of the scheme) and which is exercisable by him at his discretion but only as 'trustee of the power', may be exercised only by the independent trustee.

The question of whether or not a particular power exercisable by the employer is held by it 'as trustee of the power' is a very difficult one. It is generally thought that this is designed to cover fiduciary powers. Fiduciary powers are those held by the company in its fiduciary capacity so that the company owes a fiduciary duty to the trust beneficiaries as to how and when to exercise the power. The fiduciary powers can be distinguished from other powers known as 'beneficial' powers. These are powers held by the company in a beneficial capacity so that it may exercise them in its own interest and for its own benefit.

The issue as to whether particular powers in a pension scheme are fiduciary or beneficial in nature is not absolutely clear at present, as English case law has failed to provide clarity on the issue. However, it is generally accepted that most powers will be beneficial and not fiduciary in nature. For example, the power of the employer to agree with the trustee of the scheme to amend the scheme rules or augment benefits has been held to be beneficial.

To summarise then, all the powers of the trustees and the fiduciary powers of the employer under the scheme will vest in the independent trustee.

Beneficial powers remain exercisable by the employer, acting through the insolvency practitioner (or official receiver).

\section{Payment of the independent trustee}

An independent trustee is entitled to be paid his reasonable fees for acting as an independent trustee and any expenses reasonably incurred by him in doing so out of the scheme's resources despite any provisions of the scheme's trust deed and rules. Such payments are payable in priority to all other claims to be met out of the scheme's resources by virtue of $s$. 25(6) of the Act. ${ }^{14}$

\section{When does the obligation to have an independent trustee end?}

Section 22 (2) of the $\mathrm{Act}^{15}$ provides that s. $22^{16}$ ceases to apply in relation to a scheme if:

(a) some person other than the insolvent company becomes the employer ('employer' meaning the employer of the persons in the description or category of employment to which the scheme relates); or

(b) the insolvency practitioner ceases to act in relation to the employer.'

These provisions are modified in relation to a multi-employer scheme by the Independent Trustee Regulations. These provide that s. $22^{17}$ shall not cease to apply to the scheme as a result of s. $22(2)(a)^{18}$ unless the power to appoint and remove any trustee of the scheme is transferred to a person other than the employer concerned (ie the person who becomes the employer of persons in the relevant description), or to any person who is independent for the purposes of the legislation.

It would appear that s. $22(2)(a)^{19}$ is geared to deal with the situation where a company ceases to participate in a scheme as an employer and all its employees transfer out to a new employer, for instance as part of a 
$\mathrm{TUPE}^{20}$ transfer on a business sale where the new employer takes over the scheme and the rights of the previous employer.

\section{References}

1 Section 22 Pensions Act 1995.

2 Occupational Pension Schemes (Independent Trustee) Regulations 1997.

3 Section 22-26 Pensions Act 1995.

4 Reg 3 Occupational Pension Schemes (Independent Trustee) Regulations 1997.

5 Section 22 Pensions Act 1995.

6 Section 23(3) Pensions Act 1995.
7 Regulation 2 Occupational Pension Schemes (Independent Trustee) Regulations 1997.

8 Section 22 Pensions Act 1995.

9 Section 22 Pensions Act 1995.

10 Section 23 Pensions Act 1995.

11 Section 23(1)(a) Pensions Act 1995.

12 Section 26A, 26B, 26C Pensions Act 1995.

13 Sections 22-26 Pensions Act 1995.

14 Section 25(6) Pensions Act 1995.

15 Section 22(2) Pensions Act 1995.

16 Section 22 Pensions Act 1995.

17 Section 22 Pensions Act 1995.

18 Section 22(2)(a) Pensions Act 1995.

19 Section 22(2)(a) Pensions Act 1995.

20 Transfer of Undertakings (Protection of Employment) Regulations 1981. 